\title{
Loan-to-Value Policy and Property Loans Risk in Conventional Commercial Banks of Indonesia
}

\author{
Nugroho Sasikirono*; Syelma Sumanto**; I Made Sudana*; \\ Harlina Meidiaswati*** \\ * Faculty of Economics and Business, Universitas Airlangga \\ *** PT Mandiri Sekuritas \\ **** Faculty of Economics, Kartini University
}

\begin{tabular}{l|l}
\hline A R T I C L E I N F O & A B S T R A C T \\
\hline $\begin{array}{l}\text { Keywords: } \\
\text { loan-to-value policy, } \\
\text { bank risk, } \\
\text { property loan risks, } \\
\text { non-performing loans, } \\
\text { Indonesia }\end{array}$ & $\begin{array}{l}\text { This study aims to determine the effect of loan-to-value (LTV) policy on } \\
\text { bank's property loan risk of Indonesia. This study utilizes a purposive } \\
\text { sampling method and multiple linear regression analysis techniques. } \\
\text { The number of samples in this study is } 66 \text { banks with } 563 \text { observations } \\
\text { data. The results show that bank's property loan risk, which is proxied } \\
\text { by the NPL ratio of property loans, is lower in the LTV tightening policy } \\
\text { period than the easing period. We utilize some control variables in this } \\
\begin{array}{l}\text { Kebijakan Loan-to-Value, } \\
\text { Risiko bank, }\end{array} \\
\begin{array}{l}\text { Pinjaman Ninjaman properti, } \\
\text { Indonesia }\end{array}\end{array} \quad \begin{array}{l}\text { study: inflation, gross domestic product growth, property loan growth, and } \\
\text { positive effect on non-performing loans, while gross domestic product } \\
\text { growth has a significant negative effect. }\end{array}$
\end{tabular}

\section{SARI PATI}

Penelitian ini bertujuan untuk mengetahui pengaruh kebijakan loanto-value (LTV) pada risiko pinjaman properti bank. Penelitian ini menggunakan metode purposive sampling dan teknik analisis regresi linier berganda. Jumlah sampel dalam penelitian ini adalah 66 bank dengan 563 data pengamatan. Hasil penelitian menunjukkan bahwa risiko pinjaman properti bank, yang diproksi dengan rasio NPL pinjaman properti, lebih rendah pada periode kebijakan pengetatan LTV daripada periode pelonggaran. Kami menggunakan beberapa variabel kontrol dalam penelitian ini: inflasi, pertumbuhan produk domestik bruto, pertumbuhan kredit properti, dan ukuran bank. Inflasi, pertumbuhan kredit properti, dan ukuran bank memiliki pengaruh positif yang signifikan terhadap kredit bermasalah, sementara pertumbuhan produk domestik bruto memiliki efek negatif yang signifikan. 


\section{INTRODUCTION}

The demand for property sector products, driven by consumption and investment motives, has an effect on the rising of property prices. Nevertheless, the increase in demand is often not accompanied by an increase in the financial capacity of prospective buyers. To overcome the gap between the increase in property prices and the financial ability of prospective buyers, banks carry out the function of financial intermediary institutions by distributing property loans facilities. The trend of rising prices for property sector products can be beneficial for banks because it encourages credit expansion. Even so, if it is not balanced with adequate prudential rules, credit expansion can actually increase the bank's business risk (Bian et al., 2018). The excessive expansion of property loans can create a risk of non-performing loans to banks; which in aggregate can create systemic risk in a country's financial system. In order to overcome the threat of systemic risk arising from the property sector credit, Bank Indonesia implemented a macroprudential policy in the form of loan-to-value (LTV).

Macroprudential policy, only popular after the global financial crisis that occurred in 2008 (Bank Indonesia, 2016). The crisis triggered by the problems of subprime mortgages in the property and financial sector ultimately affected the world economy. Since the global financial crisis, loan-tovalue policies have begun to become the focus of attention of developed and developing countries in order to control systemic risk (Morgan et al., 2015). The LTV policy regulates the maximum percentage of property loans that the bank can approve to prospective borrowers from the total value of the property purchased. For example, the $80 \%$ LTV ratio means that the bank can provide loans with a maximum value of $80 \%$ of the property price and the debtor needs to pay down payment of $20 \%$.

The loan-to-value (LTV) policies that were once set by Bank Indonesia can be divided into a tightening and easing policy. Tightening of LTV began to be implemented from June 2012 to May 2015, while easing began to take effect from June 2015 to July 2018. In the tightening policy, Bank Indonesia lowered the LTV ratio with the aim of restraining the high growth of property loans, because it was feared could bubble up property prices and increase credit risk for the bank. The easing policy means that Bank Indonesia increases the LTV ratio with the aim of increasing bank lending which is fairly low.

Some studies show different results regarding the effect of loan-to-value policies on non-performing loans or non-performing loans. Pirgaip and Hepsen (2018) found that the policy of tightening loan-tovalue in Turkey proved to be able to overcome excessive bank non-performing loans. In contrast, the research of Ascarya et al. (2016) prove that the tightening of LTV actually has a significant impact in increasing the risk of non-performing loans to banks.

Based on the above phenomenon, the problem in this study is defined as: "Is there an effect of the loan-to-value tightening policy on non-performing loans of bank property loans?". Thus, the purpose of this study is to determine the effect of loan-tovalue tightening policies on non-performing loans of bank property loans.

\section{THEORETICAL BACKGROUND AND HYPOTHESIS} DEVELOPMENT

Definition and measurement of bank property loans risk

One type of credit offered by banks is property loans, which are loans channeled by banks to debtors for ownership of assets in the form of houses, apartments, shops and/or offices. Banks running the property loan function will face the risk of property loans. This is a risk due to failure or inability of the debtor to pay the principal and/or interest in the installment of the property within a predetermined period of time. The risk of problem loans in property loans is also called non-performing loans (NPL) of property loans.

According to the 2016 Bank Indonesia Circular Letter No.18 / 19 / DKMP, the ratio of non-performing 
loans of property loans is the comparison between the summation of property loans classified as substandard, doubtful and loss as stipulated by Bank Indonesia to the total property loans delivered by a bank. The calculation formula for the ratio of nonperforming loans of property loans is as follows:

$N P L P_{i, t}=\frac{S S D L_{i, t}}{\operatorname{Total} P L_{i, t}} \times 100 \%$

Description:

NPLP $_{i, t} \quad$ : the ratio of non-performing loans of property loans at bank $i$ in the quarter $t$

$\mathrm{SSDL}_{\mathrm{i}, \mathrm{t}} \quad$ : the summation of property loans classified as substandard (SS), doubtful (D) and loss (L) at bank $\mathrm{i}$ in the quarter $\mathrm{t}$

Total $\mathrm{PL}_{\mathrm{i}, \mathrm{t}}$ : the total property loans delivered by bank $\mathrm{i}$ in the quarter $\mathrm{t}$

The higher the NPL ratio of property loans of a bank, the greater the risk of default on property loans. If this ratio continues to increase, banks will suffer losses because they do not receive loan principal payments from debtors, and do not get profit from interest on property loans. If the loss continues to accumulate, it can disrupt the bank's liquidity.

\section{Definition Loan-to-Value policy and its effect on the} risk of bank property loans

The loan-to-value (LTV) policy is a macroprudential policy to control the rate of growth in property loans and credit risk that can be generated. Loan-to-value policies limit the maximum percentage of property loans that banks can send to prospective borrowers against the total value of property that is used as collateral. In Bank Indonesia Circular Letter No.18 / 19 / DKMP, "the ratio of loan-to-value is the ratio number between the credit value that can be given by the bank to the value of collateral in the form of property at the time of credit based on the results of the last assessment".

The loan-to-value policy not only affects the growth of property loans but also indirectly impacts the risk of bank property loans. In the LTV tightening policy period, banks can only provide loans with a relatively low percentage of property prices, so that prospective buyers need to pay a higher down payment. The higher down payment that must be paid will result in only good quality debtors who are able to apply for property loans. The impact of this policy is the low NPL of property loans. Likewise, in the period of the LTV easing policy, banks are able to provide loans with a high percentage of property prices, so that people only had to pay a low down payment. If the down payment that needs to be paid is low, then prospective debtors with poor quality also have the opportunity to apply for property loans. This can lead to the high NPL of property loans.

Morgan et al. (2018), argues that the LTV tightening policy can be used to hold back the level of NPLs. Likewise, the LTV easing policy is believed to encourage the delivery of property loans, so banks need to pay attention to the potential increase in NPLs (Mangeswuri, 2018). Thus, the LTV tightening policy can reduce the risk of property loans, while easing can increase risk. Nevertheless, Ascarya et al. (2016), proving that the policy of tightening LTV actually increases the risk of non-performing loans. Based on previous explanations, the research hypothesis is arranged as:

$\mathrm{H}_{1}$ : There is a negative effect of the loan-to-value policy on non-performing loans; which is indicated by the lower non-performing loans of bank property loans in the LTV of tightening period compared to the easing period.

\section{Other factors that contribute to the risk of bank property loans}

According to Abid et al. (2014); Louzis et al. (2012); Messai and Jouini (2013), there are several factors that can affect a bank's non-performing loan:

\section{Inflation rate}

The higher the inflation rate the lower the purchasing power of the people due to the rising in prices while the income is relatively fixed. In conditions of rising inflation, debtors tend to prioritize meeting daily needs first 
and delay payment of property loans, thereby increasing the risk of non-performing loans for banks in the following period. Thus, the inflation rate has a positive effect on the risk of bank property loans. Klein (2013), Touny and Shehab (2015) prove the positive influence of the inflation rate on non-performing loans.

\section{The growth of Gross Domestic Product}

The positive growth of the Gross Domestic Product (GDP), otherwise known as economic growth, will expand employment, enhance the productivity of business people, and increase the income and welfare of the community (Pambudi, 2013). Thus, the debtor's ability to pay for property loans is not hampered, which results in the lower risk of bank non-performed loans. Therefore, in the higher GDP growth rate, the risk of bank property loans will be lower. Abid et al. (2014); Louzis et al. (2012); Messai and Jouini (2013) argue that GDP growth has a negative effect on bank non-performing loans. In this study we use the GDP lagged variable.

\section{The growth of property loans}

The increase in the value of property loans delivered by banks from time to time is known as the growth of property loans. Loan growth will drive the bank's risk level (Foos et al., 2010). A bank's property loans growth is calculated by the formula:

$\Delta P L_{i, t}=\frac{P L_{i, t}-P L_{i, t-1}}{P L_{i, t-1}} \times 100 \%$

Description:

$\Delta P L_{i, t}$ : the growth of property loans at bank $\mathrm{i}$ in the quarter $\mathrm{t}$

$\mathrm{PL}_{\mathrm{i}, \mathrm{t}} \quad$ : the total value of property loans at bank $\mathrm{I}$ in the quarter $\mathrm{t}$

$\mathrm{PL}_{\mathrm{i}, \mathrm{t}-1}$ : the total value of property loans at bank I in the quarter $t-1$
High property loan growth occurred due to the implementation of loan-to-value easing policies that simplified the credit down payment requirements. The ease of property credit requirements in the form of a lower down payment causes a low-quality debtor to obtain a loan. If more and more less-qualified debtors obtain property loans, bank non-performing loans will increase. Salas and Saurina (2002) argue that credit growth has a positive effect on non-performing loans.

\section{Bank size}

Bank size indicates the size of the bank based on the number of assets held (Hendriati, 2010). The higher the asset value the greater the size of the bank. Asset ownership affects the ability of banks to manage funds that have been collected, including delivering it in the form of loans to debtors. Banks with large credit volumes have the opportunity to reduce the spread rate, which can then reduce loan interest rates (Dendawijaya, 2009: 105). Lower lending rates make banks competitive. This, in turn, will reduce the risk of non-performing loans because debtors are better able to repay loans. That way, the higher the value of assets owned by a bank the lower the risk of property loans. Ranjan and Dahl (2003) argue that bank size has a negative effect on non-performing loans. Altunbas et al. (2018) and Morgan et al. (2018), measuring bank size uses the logarithm of the total assets of the bank held for a certain period. So that the bank size formula in this research is:

$S I Z E_{i, t}=\log (T A)_{i, t}$

Description:

$S I Z E_{i, t}$ : the size of bank $\mathrm{i}$ in the quarter $\mathrm{t}$

$\mathrm{TA}_{i, t} \quad$ : the value of total assets of bank $\mathrm{i}$ in the quarter $\mathrm{t}$ 


\section{METHODOLOGY}

\section{Model}

We use multiple linear regression analysis with the model:

$N P L P_{i, t}=\beta_{0}+\beta_{1} D_{L T V t}+\beta_{2} I N F L_{t-1}+\beta_{3} \Delta G D P_{t-1}+\beta_{4}$ $\triangle P L_{i, t}+\beta_{6} S I Z E_{i, t}+\varepsilon$

Description:

$\beta_{0} \quad=$ constant

$\beta_{1}, \ldots, \beta_{4}=$ regression coefficients

$\mathrm{NPLP}_{\mathrm{i}, \mathrm{t}}=$ the ratio of non-performing loan of property loan at bank $\mathrm{i}$ in the quarter $\mathrm{t}$

$\mathrm{D}_{\text {LTVt }} \quad=$ Dummy of loan-to-value policy (valued 1 in the tightening period and 0 in easing)

$\mathrm{INFL}_{\mathrm{t}-1}=$ the inflation rate in the quarter $\mathrm{t}-1$

$\Delta \mathrm{GDP}_{\mathrm{t}-1}=$ the growth of gross domestic product in the quarter $\mathrm{t}-1$

$\Delta \mathrm{PL}_{\mathrm{i}, \mathrm{t}} \quad=$ the growth of property loans at bank $\mathrm{i}$ in the quarter $\mathrm{t}$

SIZE $_{\mathrm{i}, \mathrm{t}}=$ the size of bank $\mathrm{i}$ in the quarter $\mathrm{t}$

$\varepsilon=$ Error

\section{Data and sample}

The data in this study are include: 1) Data on nonperforming loans and on growth in bank property loans obtained from bank reports to the Financial Services Authority, 2) Data on inflation rates and GDP growth obtained from BPS-Statistics Indonesia, 3) Data on bank size obtained from bank's quarterly reports from the official website of the Financial Services Authority. We utilized a purposive sampling method with the following criteria:
1. Conventional commercial banks that deliver property loans.

2. Commercial banks that routinely submit property loan reports to the Financial Services Authority during the study period, namely in the tightening policy period (January 2013 to December 2014) and the easing period (January 2016 to December 2017).

Based on these criteria we obtained a sample of 66 banks

\section{Operational definitions}

1. The ratio of non-performing loans of property loans is a proxy for the risk of bank property loans, which is a risk due to failure or inability of the debtor to pay the principal and/or interest on the mortgage loan. This ratio is calculated by formula (1).

2. The loan-to-value policy is a Bank Indonesia policy that regulates the maximum percentage of property credit that banks can approve to prospective borrowers against the total value of the property used as collateral. Bank Indonesia announced the first LTV policy on March 15, 2012. Based on these regulations the maximum LTV value for property loans was 70\%. This policy is known as a strict LTV policy. In June 2015, Bank Indonesia issued a policy of easing LTV with a maximum ratio of $80 \%$ for home loans and $90 \%$ for apartments. The LTV policy in this study is expressed as a dummy variable, worth 1 for the tightening policy period (January 2013 to December 2014) and 0 for easing (January 2016 to December 2017).

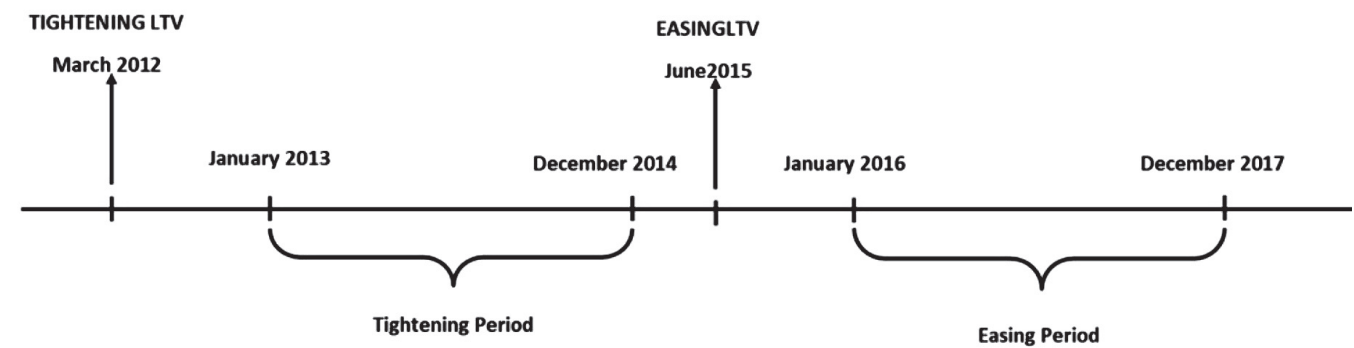

Figure 1. Observation timeline 
3. Inflation is the quarterly inflation rate obtained from BPS-Statistics Indonesia.

4. Gross domestic product growth is quarterly GDP growth obtained from BPS-Statistics Indonesia.

5. The growth of property loans is the increase in the value of a bank's property loans from quarter to quarter. Bank property loan growth is calculated by formula (2).

6. Bank size is the size of a bank based on the value of the total assets held, calculated by formula (3).

\section{RESULTS AND DISCUSSION}

\section{Descriptives}

Table 1 shows descriptions of research results. The variable of property loan risks is proxied by the ratio of non-performing loans to property loans. The lowest value of the NPLP variable is $0.00 \%$, while the highest value is $3.99 \%$. The average value of the non-performing variable loan of loan property is $1.59 \%$ with a standard deviation of $1.04 \%$. This shows that there are quite a number of banks with above-average NPLs. The loan-to-value (DLTV) policy variable measured by dummy has the lowest value of 0 in the period of easing policy and the highest value that is 1 in the Loan-to-Value tightening policy period.

The property loan growth $(\Delta \mathrm{PL})$ of the bank has the lowest growth value of $-37.71 \%$, while the highest value is $132.36 \%$. The average value of bank property loan growth is $3.18 \%$. Meanwhile, the bank size (SIZE) variable has the lowest value of 6.74 and the highest value is 14.99 . This value is the size of the bank based on the logarithm of the total assets owned.

\section{Model Analysis and Hypothesis Testing}

Table 2 shows the OLS results which are accompanied by the results of classical assumption tests. The results of the Kolmogorov-Smirnov test show a significance value of 0.065 . This result indicates that the data is normally distributed. The tolerance value is more than 0.10 and VIF is less than 10 , indicating there is no multicollinearity. The Spearman's Rho Correlation Test shows a significance value of more than 0.05 , it can be concluded that there are no symptoms of heteroscedasticity in the regression model. Runs Test produces a significance value of 0.473 , so it can be concluded that there is no autocorrelation.

The regression analysis shows that the NPLs of bank property loans in the tightening policy period, by average, is $0.613 \%$ lower than in the period of the loan-to-value easing policy. This result is in line with the condition that in the LTV tightening policy period, banks can only provide loans with a low percentage of property prices and prospective borrowers need to pay a higher down payment. Thus, only qualified debtors are able to apply for property loans. This makes the risk of bank property loans lower. The result of this study is consistent with the research of Pirgaip and Hepsen (2018) which prove that the loan-to-value tightening policy is effective in reducing the level of non-performing loans.

Inflation (INFL) has a significant positive effect on NPLs of bank property loans. The higher the inflation

Table 1. Descriptives

\begin{tabular}{lcrrrr}
\hline & $\mathrm{N}$ & Minimum & Maximum & Mean & Std. Deviation \\
\hline NPLP & 563 & 0.0000 & 3.9952 & 1.5912 & 1.0409 \\
$D L T V^{*}$ & 563 & 0 & 1 & 0.50 & 0.5000 \\
$I N F L$ & 563 & 0.2800 & 4.4300 & 1.2632 & 1.0346 \\
$\Delta G D P$ & 563 & -2.1825 & 4.0089 & 1.5479 & 2.3151 \\
$\Delta P L$ & 563 & -73.9768 & 132.3644 & 3.1821 & 14.2731 \\
SIZE* & 563 & 6.7404 & 14.9905 & 13.4586 & 0.8244 \\
\hline
\end{tabular}

Annotation: Results are in\%, except those marked with *

Source: SPSS output 
Table 2. Regression Results

\begin{tabular}{|c|c|c|c|c|c|c|c|}
\hline \multirow[t]{2}{*}{ IV } & \multirow[t]{2}{*}{ Coeff. } & \multirow[t]{2}{*}{$\mathrm{t}$} & \multirow[t]{2}{*}{ Sig. } & \multicolumn{2}{|c|}{ Multicollinearity } & \multicolumn{2}{|c|}{ Heteroskedasticity } \\
\hline & & & & Tol. & $V I F$ & Coeff. & p-value \\
\hline (Constant) & -0.388 & -0.0583 & 0.560 & & & & \\
\hline$D L T V$ & -0.613 & -7.441 & 0.000 & 0.963 & 1.038 & -0.019 & 0.645 \\
\hline INFL & 0.115 & 2.863 & 0.004 & 0.952 & 1.051 & 0.014 & 0.733 \\
\hline$\triangle G D P$ & -0.071 & -3.912 & 0.000 & 0.932 & 1.073 & 0.010 & 0.819 \\
\hline$\triangle P L$ & 0.008 & 2.900 & 0.004 & 0.973 & 1.028 & 0.004 & 0.926 \\
\hline SIZE & 0.165 & 3.359 & 0.001 & 0.995 & 1.005 & 0.019 & 0.649 \\
\hline $\mathrm{R}^{2}$ & 0.158 & & & & & & \\
\hline Adj $R^{2}$ & 0.150 & & & & & & \\
\hline $\mathrm{F}$ & $20.858, \mathrm{p}-\mathrm{I}$ & 0.000 & & & & & \\
\hline
\end{tabular}

Kolmogorov- $1.309, \mathrm{p}$-value 0.065

Smirnov Z

Runs Test Z $\quad-0.060$, p-value 0.473

rate, the lower the people's purchasing power due to the increase in prices which are not necessarily followed by an increase in income. Therefore, debtors tend to prioritize fulfilling their daily needs first and delay payment of property loans. This increases the value of bank NPLs. The results of this study are consistent with Klein (2013), and Touny and Shehab (2015), which find that inflation has a positive effect on non-performing loans.

The growth of gross domestic product ( $\Delta \mathrm{GDP}$ ) has a significant negative effect on NPLs of bank property loans. Positive economic growth will expand employment, increase the productivity of business people, and improve people's welfare and income (Pambudi, 2013). Thus, the ability of debtors to pay for property loans is not hampered, so the risk of bank property loans falls. Vice versa, negative economic growth will narrow employment, reduce business productivity, reduce people's welfare and income and even increase unemployment. This will then hamper the ability of the debtor to repay the loan so that the bank's credit risk rises. This result is consistent with results of Abid et al. (2014), Louzis et al. (2012), Messai and Jouini (2013) which states GDP growth has a positive effect on bank NPLs.

Property loan growth ( $\Delta \mathrm{PL})$ has a significant positive effect on non-performing loan bank property loans. The increase in property loan growth is due to the implementation of loan-to-value easing policies that lower the credit down payment requirements. The ease of the property loans in the form of lower down payments causes debtors with poor quality to be able to obtain loan facilities. If more and more low-quality debtors also get property loans, then the risk of bank non-performing loans will definitely increase. This result is consistent with the research of Salas and Saurina (2002) who argue that credit growth has a positive effect on non-performing loans.

Bank size (SIZE) has a significant positive effect on NPLs of bank property loans. This result is contrary to the hypothetical relationship that bank size has a negative effect on non-performing credit risk as mentioned in the research of Ranjan and Dahl (2003). This happens because banks that have large assets tend to be more daringly in taking risks by delivering credit to low-quality debtors (Gunawan and Sudaryanto, 2016). Conversely, small-sized banks tend to be more careful in lending, because it greatly affects their liquidity. Thus, this result is consistent with the research of Abid et al. (2014) and Louzis et al. (2012) which states that a bank size has a positive effect on a bank's non-performing loan.

\section{Robustness Check}

We conducted a test to find out whether the variables in the study continued to show a significant effect 
on NPLs in different LTV conditions. We separate the entire sample into two, namely the sample of tightening and easing conditions. Table 3 shows the role of LTV in determining NPLs of property loans. In both groups the absence of LTV variables negates the effect of macroeconomic variables, inflation and economic growth. This shows that the impact of macroeconomic variables will only be evident when associated with the ratio of the limit on property loans. At the company level, only size is consistently associated with NPLs of property loans. Nevertheless it can be observed that the effect of size on the tightening period is different from that of easing. In the tightening period, the bigger the bank size, the higher the NPLs. This is because the tightening of LTV encourages large banks to be more expansive than small banks in extending credit. The availability of larger funds makes banks more capable of channeling credit. This causes the lending of large banks to be less selective and increase NPLs. During the easing period, small banks became more expansive in lending. Even so, their lower ability in distributing and managing property loans makes NPLs of small banks tend to be higher than those of large banks. Credit growth in the easing period has a positive effect. This happens because in the easing period banks tend to be less selective in lending.

\section{CONCLUSION, IMPLICATION, AND LIMITATION}

The NPLs of bank property loans in the LTV tightening policy period is lower than in the easing period. This happened because in the LTV tightening policy period, banks could only provide loans with a low percentage of property prices, so only qualified debtors are able to apply for credit. Inflation has a significant positive effect on nonperforming loan bank property loans. The higher the inflation rate, the lower the people's purchasing power due to price increases that are not followed by an increase in income. Economic growth has a significant negative effect on non-performing loans of bank property loans. GDP growth will increase the ability of debtors to pay for property loans. The growth of property loans has a significant positive effect on non-performing loan bank property loans. During the implementation of the LTV easing policy, due to the low down payment of property loans, low-quality debtors could also apply for loans. Bank size has a significant positive effect on nonperforming loan bank property loans. The bigger the size of the bank, the bolder the bank in taking risks by delivering credit to low-quality debtors.

The research implication for banks that provide property loans is the need for special additional policies when implementing the changing loan-tovalue provisions of Bank Indonesia. For example, if there is an LTV easing policy, banks must be more stringent in conducting credit analysis to prospective debtors. The results of the study also emphasized the importance of regulators taking into account and considering the timing of the implementation of LTV policies, both tightening and easing policies. If the

Table 3. Regression Results of Subsamples

\begin{tabular}{lccrrrr}
\hline \multicolumn{1}{r}{ Var. } & \multicolumn{2}{c}{ Tightening Period } & \multicolumn{3}{c}{ Easing Period } \\
& Coeff & $\mathrm{t}$ & sig & Coeff & \multicolumn{1}{c}{$\mathrm{t}$} & sig \\
\hline (Constant) & -3.256 & -3.319 & 0.001 & -3.315 & -2.564 & 0.011 \\
INFL & -0.041 & -0.781 & 0.435 & -0.014 & -0.221 & 0.826 \\
$\Delta G D P$ & -0.012 & -0.507 & 0.612 & 0.013 & 0.401 & 0.689 \\
SIZE & 0.337 & 4.579 & 0.000 & -0.004 & -2.439 & 0.015 \\
$\Delta P L$ & 0.000 & -0.193 & 0.847 & 0.373 & 3.903 & 0.000 \\
\hline R2 & 0.045 & & & 0.050 & & \\
F & 5.553 & & & 5.549 & & \\
\hline
\end{tabular}

Source: SPSS output 
growth rate and risk of property loans have shown a strong trend (increasing or decreasing sharply), the regulator must immediately make adjustments or issue additional policies to control the impact that can occur.

This study limits analysis only to the impact of changes in LTV on the NPL of property loans. Further research can be directed at the impact of changes in LTV on the growth of property loans. Further research can also be done by utilizing other bank specific variables in explaining the NPL of property loans.

\section{ACKNOWLEDGEMENT}

We would like to thank the Financial Services Authority (OJK), which has been pleased to provide the data we need for this research.

\section{REFEREN CES}

Abid, L., Ouertani, M. N., \& Zouari-Ghorbel, S. (2014). Macroeconomic and Bank-Specific Determinants of Household 's NonPerforming Loans in Tunisia : a Dynamic Panel Data. Procedia Economics and Finance, 13, 58-68.

Altunbas, Y., Binici, M., \& Gambacorta, L. (2018). Macroprudential policy and bank risk. Journal of International Money and Finance, 81, 203-220.

Ascarya, Rahmawati, S., \& Karim, A. (2016). Effectiveness of LTV / FTV as Macroprudential Instrument under Dual Banking System in Indonesia. In 11th International Conference on Islamic Economics and Finance Effectiveness.

Bank Indonesia. (2016). Analyzing Macroprudential Policy. (Department of Macroprudential Policy, Ed.). Jakarta.

Bian, X., Lin, Z., \& Liu, Y. (2018). House price , loan-to-value ratio and credit risk. Journal of Banking and Finance, 92, 1-12.

Dendawijaya, L. (2009). Bank Management. Jakarta: Ghalia Indonesia.

Foos, D., Norden, L., \& Weber, M. (2010). Loan growth and riskiness of banks. Journal of Banking and Finance, 34(12), 29292940.

Gunawan, A., \& Sudaryanto, B. (2016). Analysis of the Effect of Performance, Size, Inefficiency, Capital, and Third Party Funds on Non-Performing Loans (Study on Conventional Public Commercial Banks in Indonesia Period 2011-2015). Diponegoro Journal of Management, 5(3), 2337-3792.

Hendriati, R. A. (2010). Bank Size, Income Composition, and Earning Volatility Bank. (Undergraduate thesis). Universitas Airlangga.

Klein, N. (2013). Non-Performing Loans in CESEE : Determinants and Impact on Macroeconomic Performance. IMF Working Paper, WP/13/72

Louzis, D. P., Vouldis, A. T., \& Metaxas, V. L. (2012). Macroeconomic and bank-specific determinants of non-performing loans in Greece : A comparative study of mortgage, business and consumer loan portfolios. Journal of Banking and Finance, 36(4), 1012-1027.

Mangeswuri, D. R. (2018). Loan-To-Value Easing Policy. Info Singkat Bidang Ekonomi dan Kebijakan Publik Pusat Penelitian Badan Keahlian DPR RI. Vol.X, No.13/I/Puslit/Juli/2018.

Messai, A. S., \& Jouini, F. (2013). Micro and Macro Determinants of Non-performing Loans. International Journal of Economics and Financial Issues, 3(4), 852-860. 
Morgan, P. J., Regis, P., \& Salike, N. (2015). Loan-to-Value Policy as a Macroprudential Tool: The Case of Residential Mortgage Loans in Asia. ADBI Working Paper Series, 5, 528.

Morgan, P. J., José, P., \& Salike, N. (2018). LTV policy as a macroprudential tool and its effects on residential mortgage loans. Journal of Financial Intermediation Journal, 37, 89-103.

Pambudi, E.W. (2013). Economic Growth Analysis and Affecting Factors (Districts/Cities in Central Java Province). Thesis. Faculty of Economics and Business Universitas Diponegoro.

Pirgaip, B., \& Hepsen, A. (2018). Loan-to-value policy : evidence from Turkish dual banking system. International Journal of Islamic and Middle Eastern Finance and Management, 10, 1108.

Ranjan, R., \& Dhal, S. (2003). Non-Performing Loans and Terms of Credit of Public Sector Banks in India: An Empirical Assessment. Reserve Bank of India Occasional Papers, 24(3), 83-121.

Salas, V., \& Saurina, J. (2002). Credit Risk in Two Institutional Regimes: Spanish Commercial and Savings Banks. Journal of Financial Services Research, 22, 203-224.

Touny, M.A., \& Shehab, M.A. (2015). Macroeconomic Determinants of Non-Performing Loans: An Empirical Study Macroeconomic Determinants of Non-Performing Loans : An Empirical Study of Some Arab Countries. American Journal of Economics and Business Administration, 7, 11-22.

Us, V. (2017). Dynamics of non-performing loans in the Turkish banking sector by an ownership breakdown : The impact of the global crisis. Finance Research Letters, 20, 109-117. 